THE SAMBURU 



\title{
THE SAMBURU
}

\author{
A Study of Gerontocracy \\ in a Nomadic Tribe
}

by

PAUL SPENCER

1965

UNIVERSITY OF GALIFORNIA PRESS

BERKELEY AND LOS ANGELES 
University of California Press

Berkeley and Los Angeles

California

(1) Paul Spencer 1965

Printed in Great Britain 
TO MY PARENTS

\section{BROTHERS AND SISTERS}


